${ }^{0}$ Entomologica Fennica. 10 December 1998

\title{
The karyotype and morphology of Chironomus brevidentatus sp. n. (Dipt., Chironomidae). A species with a "salinarius type" larva from northern Finland
}

\author{
Mauri Hirvenoja and Paraskeva Michailova
}

Hirvenoja, M. \& Michailova, P. 1998: The karyotype and morphology of Chironomus brevidentatus sp. n. (Dipt., Chironomidae). A species with a "salinarius type" larva from northern Finland. — Entomol. Fennica 9: 225-236.

The karyotype and morphology of Chironomus brevidentatus sp. n. has been described from the Lokka reservoir in northern Finland. The species belongs to the thummi complex with the chromosome arm combination $\mathrm{AB}, \mathrm{CD}, \mathrm{EF}$ and $\mathrm{G}$. The relationships between the karyotypes of C.brevidentatus, $C$. major Wülker \& Butler, C. neocorax Wülker and Butler, C. tardus Butler, and "Chironomus sp. $2 \mathrm{n}=6$, Lokka" are described. The external morphology has been compared with the suggested nearest relatives or otherwise similar species. The known ecological conditions in the type locality are discussed.

Mauri Hirvenoja, Sotilaskorventie 13, FIN-01730 Vantaa, Finland

Paraskeva Michailova, Institute of Zoology, Bulgarian Academy of Sciences, 1 Tzar Osvoboditel boulv., 1000 Sofia, Bulgaria.

E-mail: zoology@bgcict.acad.bg

Received 16 July 1997, accepted 2 February 1998

\section{Introduction}

Wülker and Butler (1983) included six species in a group of freshwater Chironomus species, the larvae of which lack tubuli laterales of abdominal segment 7 and tubuli ventrales of abdominal segment 8 ("salinarius type" larvae). Karyologically they belong to the thummi complex with the chromosome arm combination $\mathrm{AB}, \mathrm{CD}, \mathrm{EF}$ and $\mathrm{G}$. However, one of them C. major Wülker \& Butler has the chromosome arm combination $\mathrm{AB}, \mathrm{CD}$, FEG (the $\mathrm{G}$ chromosome is fused with the $\mathrm{EF}$ chromosome.) The same process is observed in a species from the Lokka reservoir in northern Finland (Michailova 1992; in the present paper " $\mathrm{Chi}$ ronomus sp. $2 \mathrm{n}=6$, Lokka"), which is distin- guished by specific banding patterns in arms A, $\mathrm{B}, \mathrm{C}$ and $\mathrm{G}$. The larvae of this probably new species were sampled in June1989 from the eastern part of the Lokka reservoir in shallow (1-2 m) water. The rearing of the few additional similar larvae found in the same site was not succesful and the pupae and adults are therefore still unknown.

Numerous relatively small larvae of another species of the same larval type were abundantly found during a sampling period between 20 and 25 June 1995 also from northern Lokka at a depth of 4-6 m. Some of the larvae were succesfully reared to the adult stage so we can describe here both the karyotype and different instars of a new species. 


\section{Chironomus brevidentatus sp. $\mathrm{n}$.}

Holotype, a chromososome squash with the head capsule of the larva and paratypes 10 chromosome squashes with the head capsules of the larvae as well as a reared male with its pupal exuviae are in the collection of P. Michailova, Institute of Zoology, Bulgarian Academy of Sciences, Sofia, Bulgaria. Other paratypes, one chromosome squash,two males and two females with their pupal exuviae are in the collection of M. Hirvenoja, Vantaa, Finland,The material has been collected from Sodankylä, Lokka, Finland 22 June 1995 by the Hirvenoja family.

\subsection{Karyology}

\subsubsection{Material and methods}

The fourth instar larvae used for karyological analyses were fixed in absolute ethyl alcohol — glacial acetic acid (3:1). Salivary gland chromosomes were analysed from 12 specimens by applying general accepted aceto-orcein method. The larvae from which the salivary glands were removed and squashed were treated in $10 \% \mathrm{KOH}$ and mounted for external morphological analysis. The comparison of banding pattern was done with certain species of larvae of the "salinarius type" (Wülker and Butler 1983, Michailova 1992).

\subsection{Karyotype}

The chromosome set $2 \mathrm{n}=8$, with chromosome arm combination $\mathrm{AB}, \mathrm{CD}, \mathrm{EF}, \mathrm{G}$. Chromosomes $\mathrm{AB}, \mathrm{CD}$ are metacentric, chromosome EF submetacentric and chromosome $\mathrm{G}$ telocentric. So, this species belongs karyologically to the thummi complex. The centromere regions of chromosomes $\mathrm{AB}, \mathrm{CD}$ are not well expressed. Chromosomes $\mathrm{EF}$ and $\mathrm{G}$ have well heterochromatized centromere regions. All the chromosomes have poor, unclear structures.

Arm A. Similar to C. neocorax Wülker and Butler. The banding pattern in the middle part of the arm is inverted in comparison with those of C. neocorax. The sequence of bands is: $1-2 \mathrm{c}-10$ 12-3-2d-13-2k-6-5-4-7-8-9-14-19 (Fig. 1a). The section of centromere region shows a high functional activity.

Arm B. Similar to C. major Wülker and Butler and C. tardus Butler. In the middle of this arm there is a small homozygous inversion (Fig. 1a).
However, the bands of this arm are not so compact and they have a slight grain structure.

Arm C. Similar to C. major. However, with an inversion so, that the typical constriction is near to the centromere region (Fig. 1b). Also, it is distinguished by this inversion from arm $\mathrm{C}$ of Chironomus sp. $(2 \mathrm{n}=6)$. The centromere region is in a decondensed state.

Arm D. Similar to C. major and C. neocorax. With a high degree of decondensation. There is an active section (Fig. 1b) near to the centromere region.

Arm E. Similar or almost identical to C. tardus, C. neocorax, "Chironomus sp. $2 \mathrm{n}=6$, Lokka" (Michailova 1992) and C. cingulatus Meigen (Keyl 1962) (Fig. 1c). The banding pattern is: 1-3c-510b-4-3f-10c-13.

Arm F. Similar to C. tardus and C. major. The banding pattern is $1-10,17-11-18-23$ (Fig. 1c).

Arm G. Similar to $C$. neocorax. With a nucleolus at one end of the chromosome and two Balbiani rings at the other end. The Balbiani rings are separated by dark bands (Fig. 1d).

A chromosome polymorphism has not been observed.

\subsection{The morphology of $C$. brevidentatus sp. n.}

\subsubsection{Male $(N=3)$}

$A R$ 3.7-4.0. Frontal tubercles $<40-50 \mu \mathrm{m}$. Palps (2-5): 70, 260-300, 230-280 and 300-330 $\mu \mathrm{m}$. A dark species; $23-25 d c$ setae on pale spots. Wing 4.3-4.5 mm. $L R: P_{1} 1.36-1.39, P_{2} 0.60-0.63, P_{3}$ $0.69-0.73$. Number of sensilla chaetica: (distally in) $P_{2} / T a_{1} 9-15, P_{3} / T a_{1} 7-11 . B R: P_{1} 2.1-2.5, P_{2}$ 1.9-3.3, $P_{3}$ 4.7-5.5. Legs in $\mu \mathrm{m}$ :

$\begin{array}{lccc} & \text { Fore leg } & \text { Mid leg } & \text { Hind leg } \\ \text { Femur } & 1550-1700 & 1750-1860 & 2000-2100 \\ \text { Tibia } & 1450-1550 & 1650-1750 & 2000-2160 \\ \text { Tarsus 1 } & 2000-2150 & 1030-1050 & 1450-1500 \\ \text { Tarsus 2 } & 1110-1250 & 630-670 & 870-950 \\ \text { Tarsus 3 } & 820-860 & 460-500 & 650-700 \\ \text { Tarsus 4 } & 620-700 & 260-330 & 380-400 \\ \text { Tarsus 5 } & 300-340 & 200-200 & 210-240\end{array}$

The hypopygium as illustrated in Fig. 2. A quite broad processus analis tapering towards the apex, width proximally about $80-90 \mu \mathrm{m}$. The relation width of anal point/width of appendage 1 


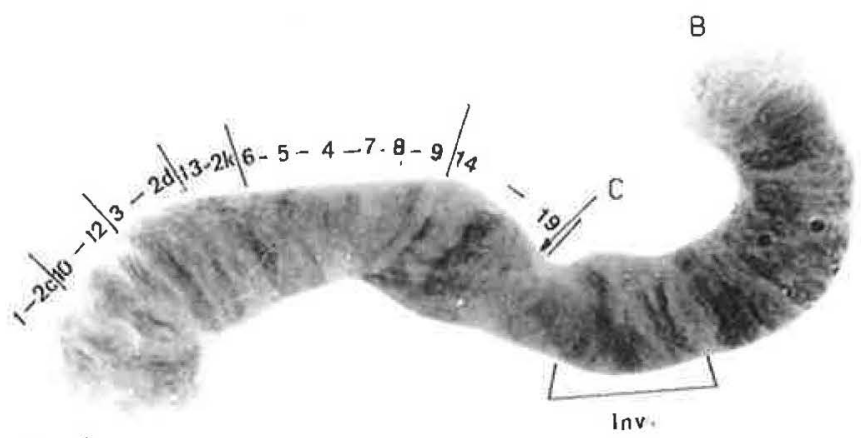

a. A

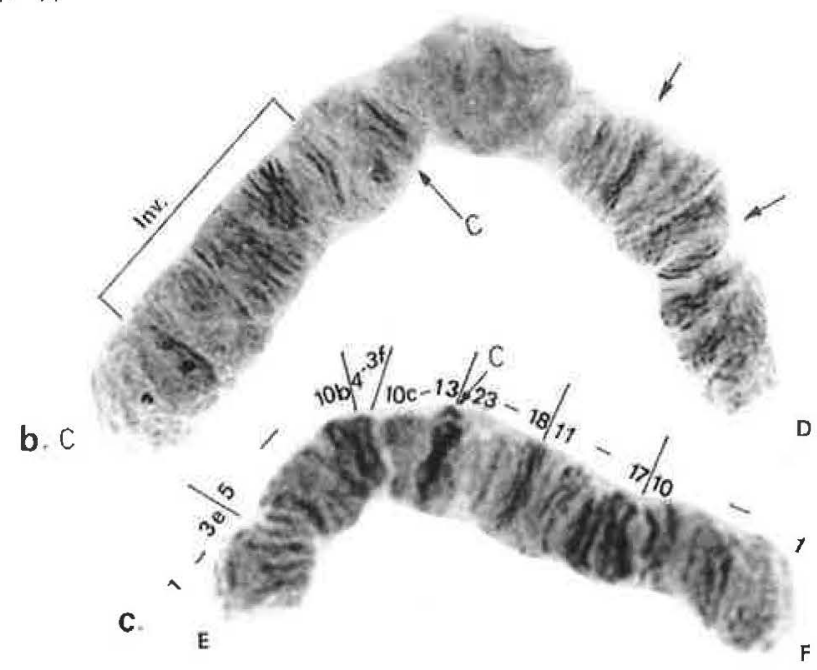

Fig. 1. Chironomus brevidentatus sp. n., chromosome AB (a); chromosome CD (b); chromosome EF (c); chromosome $\mathrm{G}(\mathrm{d}) ; \mathrm{BR}=$ Balbiani ring, $\mathrm{C}=$ centromere, inv. $=$ inversion, arrow = typical region. Scale $=10 \mu \mathrm{m}$.

d.

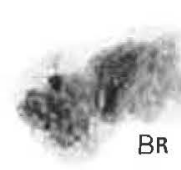

BR

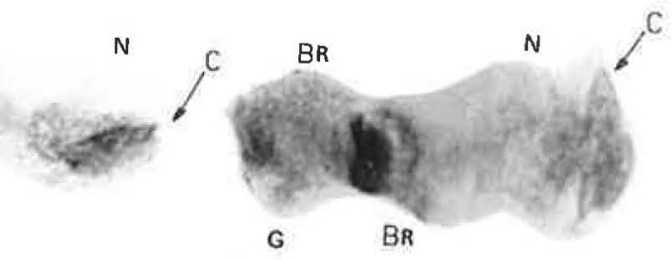

about 2.0 (as measured by Lindeberg \& Wiederholm 1979). Appendage 1 about 4 times as long as broad. Appendage 2 about 3.5-4 times as long as broad.

\subsubsection{Female $(N=2)$}

Palps (2-5): 60, 200-230, 220, 340 $\mu \mathrm{m}$. Wing 4.54.9 mm. $L R: P_{I} 1.38-1.43, P_{2} 0.59, P_{3} 0.69-0.79$. Number of sensilla chaetica: $P_{2} / T a_{1} 46-53, P_{3} /$ Ta 49-54. BR: $P_{1}$ 1.9-2.1, $P_{2}$ 1.4-2.1, $P_{3}$ 3.0-4.4.
Legs in $\mu \mathrm{m}$ :

$\begin{array}{lccc} & \text { Fore leg } & \text { Mid leg } & \text { Hind leg } \\ \text { Femur } & 1620-1620 & 1800-1800 & 2000-2020 \\ \text { Tibia } & 1390-1450 & 1690-1690 & 2050-2090 \\ \text { Tarsus 1 } & 1990-2000 & 990-1000 & 1450-1620 \\ \text { Tarsus 2 } & 1030-1060 & 550-570 & 850-900 \\ \text { Tarsus 3 } & 750-800 & 400-410 & 620-700 \\ \text { Tarsus 4 } & 600-650 & 260-260 & 340-360 \\ \text { Tarsus 5 } & 300-340 & 190-200 & 210-240\end{array}$

Spermathecae oval, $160 \mu \mathrm{m}$ long; $35-40$ setae on both sides of the sternite 8 . 


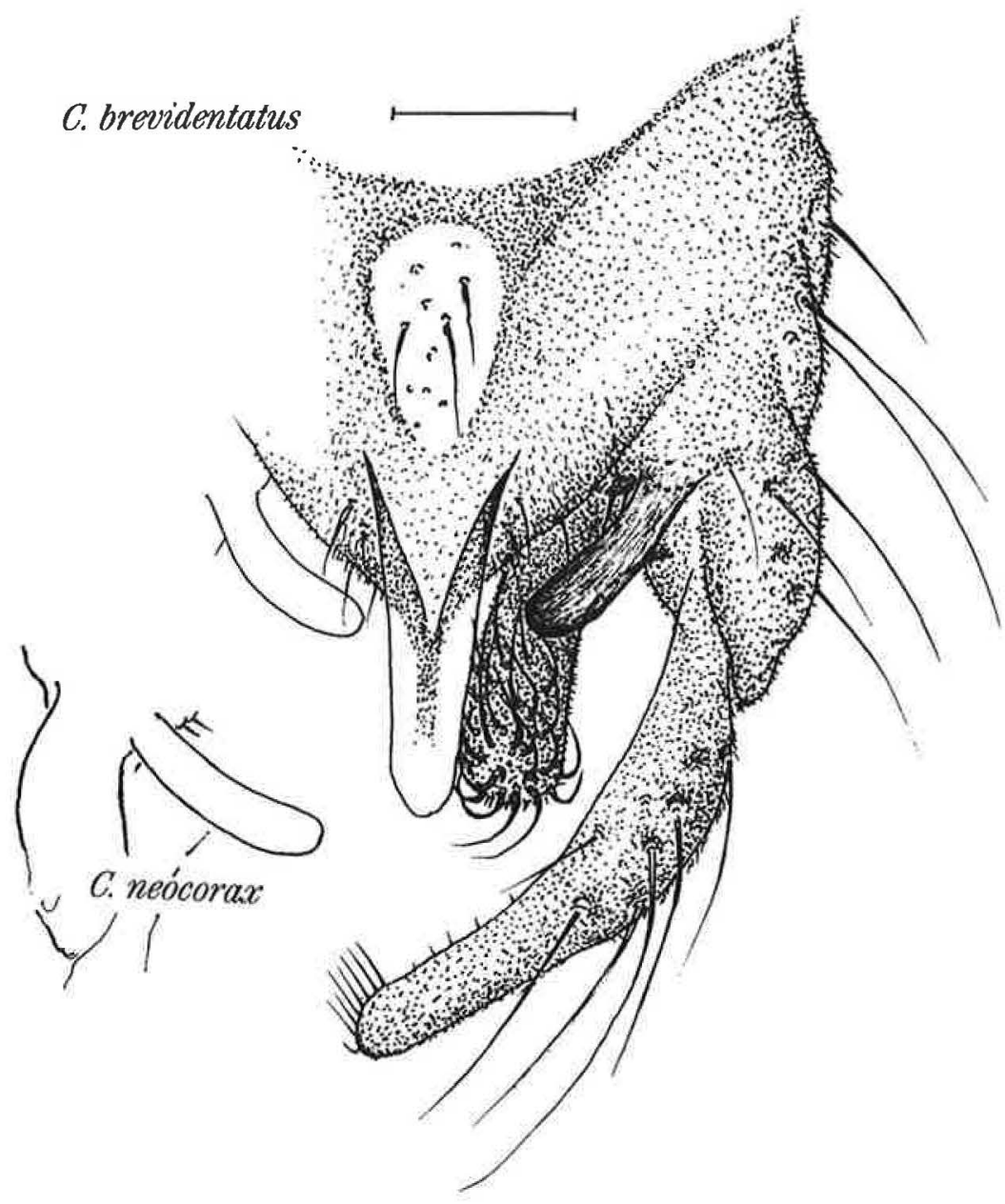

Fig. 2. Chironomus brevidentatus sp. n., hypopygium of the male and C. neocorax Wülker \& Butler, appendage 1 (1a) of the male hypopygium. Scale $=100 \mu \mathrm{m}$.

\subsection{3. $P$ upa $(N=5$, Fig. 3)}

Exuviae 9.5-10.0 mm long; abdomen quite pale, thorax a little darker and antero-dorsally relatively weakly granulated to the base of the wing sheats. Frontal apotome with voluminous cephalic tubercles, proximally near another, up to about $250 \mu \mathrm{m}$ long and $150 \mu \mathrm{m}$ broad, each with a small preapical seta. Basal ring $160-180 \times 80-100 \mu \mathrm{m}$, its tracheal patch with about $<15$ tracheoles across , about $3 \mu \mathrm{m}$ in diameter.

Shagreen on tergites typical of the genus extending laterally usually not over the anteromedial group of adhesion marks; the shagreen on tergites 2 and 6 narrower than on those of 3-5. On segments 5 and 6 spinules on paratergites present ending to a group of stronger spines in the anal cor- ner of the segment; on the anal corner of segment 7 at most few spines have been observed. On segment 2 quite large pedes spurii B and 81-104 hooklets present, the latter, especially in the middle of the row with several minute dorsal denticles. Other intersegmental orally directed spinules, which are present at least close behind the armament of tergites 4 and 5, seem to be absent behind tergite 6.

The shagreen of the sternites is very fine. Some few $10-20 \mu \mathrm{m}$ long points has been found in some exuviae on the pleural region on segment 4 near the 3rd seta only. Lateral longitudinal rows of spinules on sternites $1-4(5)$ present; antero-medial patches of spinules on sternites 2-4. (Rows of scattered lateral spinules as well as the indistinct antero-medial group on sternite 5 have been observed 

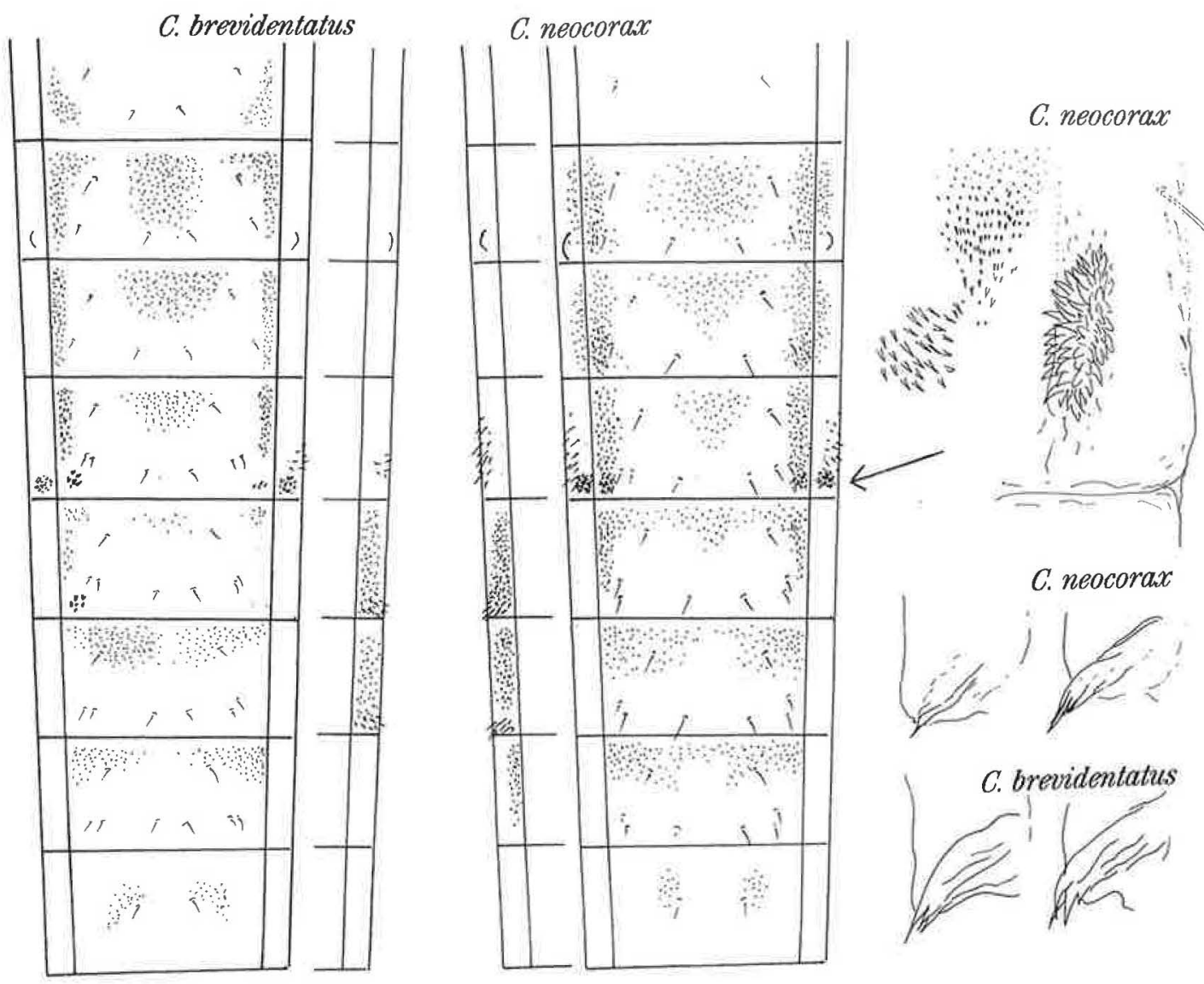

Fig. 3. Chironomus brevidentatus sp. n. and C. neocorax Wülker \& Butler, pupa. Above: frontal apotome and hooks of the hookrow. Below: sheme of the spinulation of the abdominalsternite and parasternite as well as paratergite (midst). Outermost right: enlarged area of the posterior corner of abdominalsegment 4 ventrally and analsporne of segment 8 .

in the male exuviae.) On sternite 6 the patches are larger and nearly fused, but on sternite 7 they are clearly separated; small patches of spinulae near the setae $V_{l}$ on segment 8 .

Groups of strong spinules on the postero-lateral corners of the sternite 4 are present near the group of the spines of pedes spurii A (Zavrel 1926, "vortex" Langton 1991; the latter are on parasternite 4). In one male exuviae such a group of large spinules was also postero-laterally on sternite 5 (individual variability?, determined by the sex of the animal?).

Lateral setae on segments 1-8: 0, 3, 3, 3, and taeniate $4,4,4,4$. Spurs on segment 8 with $3-5$ more-or-less long fine points apically. Anal lobe fringe of taeniae proximally uniserial, apically biserial, their number being 73-97.

\subsubsection{Larva $(N=5$, Fig. 4)}

Up to about $13 \mathrm{~mm}$ long, in the live animal quite red, without lateral or ventral tubules on the last segments; anal tubuli about $400 \mu \mathrm{m}$, gently sloping in the middle. Head capsule about $600 \mu \mathrm{m}$ long, $550 \mu \mathrm{m}$ broad, pale with a dark patch at the posterior $1 / 3$ of the length of the ventral wall of the head capsule; foramen occipitale ventrally more darkened than dorsally. Claws of the anterior pseudopods pale, at most shortly very finely 
C. brevidentatus $\quad$ neocorax
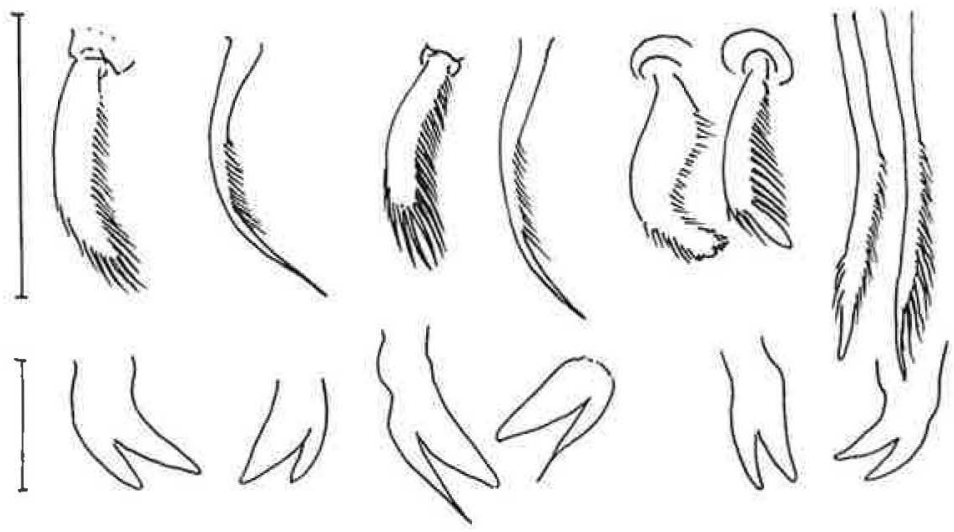

C. islandicus
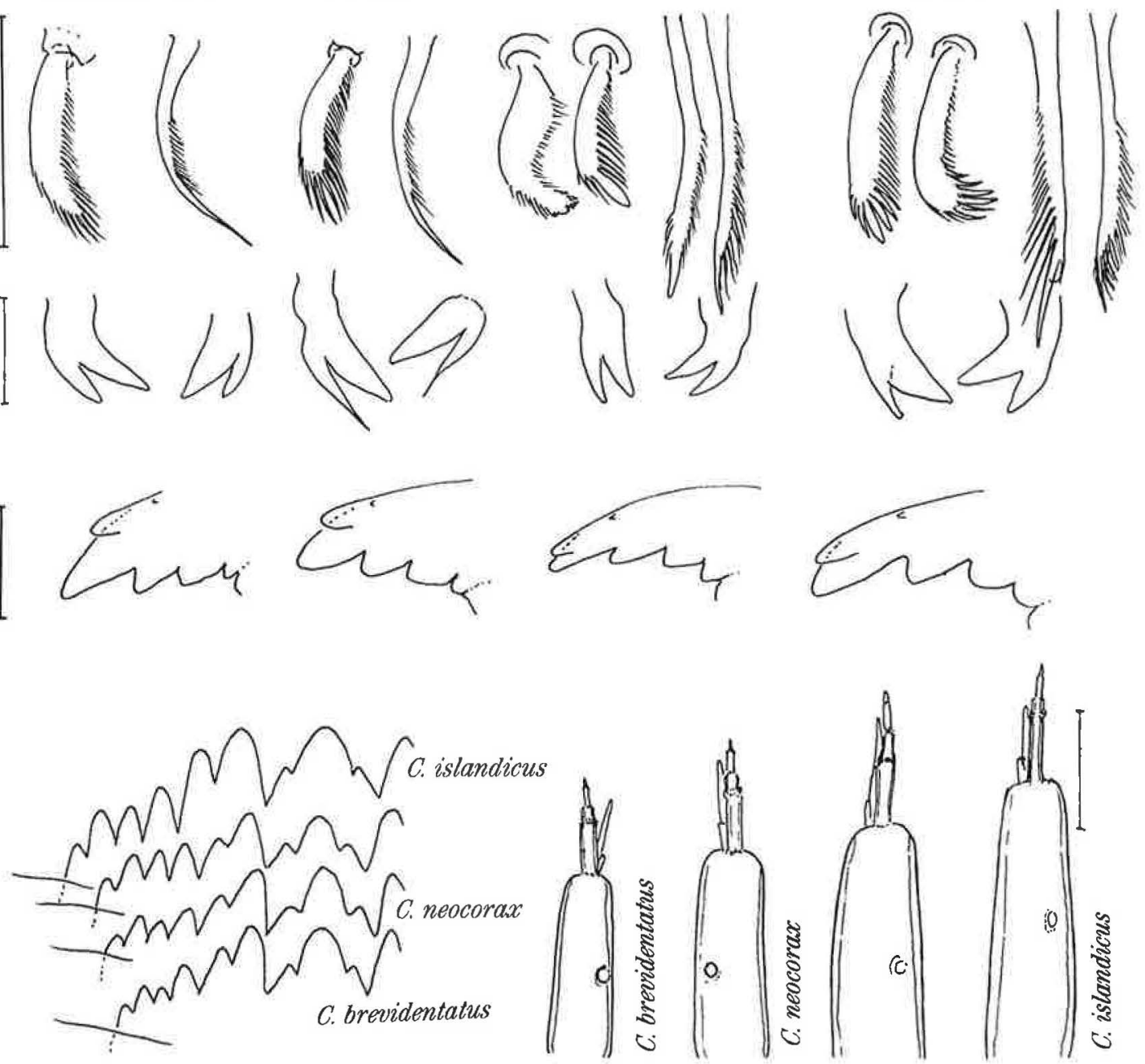

Fig. 4. Chironomus brevidentatus sp. n. and C. neocorax Wülker \& Butler, "Chironomus sp. $2 \mathrm{n}=6$, Lokka" (Michailova 1992), C. islandicus Kieffer, larva. Labrale $S_{1}$ and $C h$, apices of premandibles and mandibles, dentes of the hypochilum and antennae of each species. Scale $100 \mu \mathrm{m}$.

serrated. Claws of the posterior pseudopods pale. In the sensory field of the labrum $S_{1}$ about 45$50 \mu \mathrm{m}$ long with hairs on one side except apically on both sides; the apical flattened hairs are about equally in sitze. The median $3 \mathrm{Ch}$ setae feathered in the middle with a long bare apical part; $3-4$ short feathered chaetae are more laterally and near the tormal bar is 1 smooth very short "tooth". Pecten epipharyngis with 9-10 teeth.

Premandibles quite pale; the dorsal tooth seems to be clearly shorter than the outer or ventral tooth; both teeth not narrowly pointed. Man- dibles pale, proximally on the inner edge shortly serrated; the apical inner denticles dark except for the most proximal (6th) tooth, which is about $1 / 3$ as broad as the preceding inner teeth (5th; see Hirvenoja \& Michailova 1997). Hypochilum dark, the third tooth counting from the lateral edge smaller than the second. Paralabials with about 40 striae, which are absent in the anterior part (1/4 $1 / 3$ ), the edge of which is smooth.

Antennae about 130-160 $\mu \mathrm{m}$ long. Lauterborn organs very small. Antennal blade reaches to the 4th segment; the accessory blade is about as long 
as the 2 nd segment is broad. RO about in the proximal part of the second third of the first segment. Last segments together about a half of the length of the first; proportions of the lengths of the segments:

$$
\begin{aligned}
& 100: 29: 6: 11: 4 \\
& 100: 25: 6: 8: 5 \\
& 100: 17: 9: 12: 5
\end{aligned}
$$

\section{The relationships of $C$. brevidentatus sp.n.}

Karyologically $C$. brevidentatus is close related to $C$. tardus, $C$. major and $C$. neocorax the larvae of which belong to the "salinarius type". They are distinguished on the basis of homozygous inversions located in arms A, B and C. The results of analysis of the polytene chromosomes show that the chromosome pattern is more or less conservative with few changes from species to species. With the exception of chromosomes EF and G this species is not characterized by large heterochromatic blocks on the centromeres.

Trying to determine the male adults with the key of Pinder (1978) or with that of Lindeberg \& Wiederholm (1979) the new species C. brevidentatus resembles the European species $C$. venustus Staeger or C. longistylus Goetghebuer. Appendage 1 (1a) should be in the latter species strongly curved and distinctly darker than the remainder of the hypopygium, whereas in $C$. venustus it is slightly curved and not darker than the rest of the hypopygium. Goetghebuer (1921: 153) gives for C. venustus also a higher $L R$ 108:71 (= 1.52) than for $C$. longistylus 104:78 (= 1.33). The latter species thus resembles the suggested adults of the new species $C$. brevidentatus described here. Freshwater Chironomus larvae lacking tubuli ventrales of abdominal segment 8 and tubuli laterales of abdominal segment 7 are obviously lacking in Central Europe. A species has been redescribed by Wülker (1991) as C. longistylus from the "plumosus type" larvae, the $L R$ value being 1.50 (1.431.53 ) in the populations studied by him.

Butler (1982:223) illustrates the hypopygia of two northern nearctic species, $C$. prior Butler and C. tardus Butler, the adults of which are approximately equal in size with $C$. brevidentatus; their larvae also belong to the morphological "salinarius larval type" like that of $C$. brevidentatus. The hypopygium of $C$. prior especially resembles, according to the given illustration, that of $C$. brevidentatus, but its $A R$ value is a little lower and $L R$ higher. The number of sensilla chaetica in $C$. prior is quite equal with the male specimens of $C$. brevidentatus. (Those of the females, which are usually more clearly variable between the species, have not been given in the description.) The males of both nearctic species mentioned, in contrast to C. brevidentatus, have a moderate foretarsal BR value (4-7). They could therefore be keyed (if necessary) near the European species $C$. jonmartini Lindeberg or C. fraternus Wülker. The adult male of the nearctic species C. cucini Webb (Webb 1969; cf. also Wülker \& Butler 1983) resembles also to a certain extent that of $C$. brevidentatus.

In the palearctic species C. neocorax (Wülker \& Butler 1983: 131) the $L R$ value is a little higher (1.43-1.46) than in C. brevidentatus, which is the only difference found between the males of these species. According to the illustration the structure of the hypopygium seems to be different; the appendage 1(1a) should have an apical fold according to the illustration given by Wülker \& Butler (1983:132). Such a fold has not been observed in our mountings from the individuals (not heated in $\mathrm{KOH}$ ) of the Lake Vanajavesi, 1978, P. Kansanen leg.; the appendage 1 has at least not got "an apical knob" in C. neocorax or in C. brevidentatus. These species are equal in size and there are no differences in the number of metatarsal sensillae in the males; in C. neocorax $(\mathrm{N}=2)$ on $P_{2} / \mathrm{Ta}_{1} 8$ 12 and on $P_{3} / T a_{1} 7-10$ sensillae were observed.

In the females ( $C$. neocorax: $L R$ 1.47-1.48, N $=2$ ) it may perhaps be possible to show from more abundant materials a slight difference between C. neocorax and C. brevidentatus in the number of the sensilla chaetica. In the material of $C$. neocorax from Vanajavesi on $P_{2} / T a_{1}, 63-65$ and on $P_{3} / \mathrm{Ta}_{1}$ 64-67 sensillae were observed $(\mathrm{N}=2)$. In the individuals of $C$. neocorax prepared for the present study the receptaculum seminis had a similar shape in comparison to $C$. brevidentatus, but it was a little longer $(180 \mu \mathrm{m})$.

The pupae of $C$. neocorax and $C$. brevidentatus have the same, obviously apomorphous, quite rare features in the exuviae. These are the reduction of orally directed intersegmental spinules behind the armament of the tergites 4-7 and the occurrence 
of patches of strong spines on the anal corners of sternite 4, which may occur also on sternite 5 . The exuviae of $C$. neocorax show the origin of these patches: they are enlargened spinules of the lateral longitudinal rows of spinules of these sternites (Fig. 3). These patches in some exuviae of C. neocorax are a little separated from the row of the small spinules, in others they are fused and then they show more clearly a gradual enlargening. In C. brevidentatus the spinulation is more reduced and it would be difficult to guess the origin of the patches mentioned without the exuviae of $C$. neocorax. Such patches of strong spinules may be constructive structures and therefore in the argumentation of the relationships of the species as synapomorphous characters more reliable than the usual reduction of the spinules, which may occur in parallel in different evolutive lines. Up to now this character has been known only from the exuviae of these two species and from one perhaps undescribed species from the same study area. Fig. 3 shows the differences in the spinulation between $C$. brevidentatus and $C$. neocorax.

We have for the comparison pupal exuviae of C. islandicus Kieffer from Island and such patches of the large spinules described here from the sternites 4-5 are absent in the exuviae of this species. C. islandicus also has small intersegmental orally directed spinules behind the armament of the tergites 4-6 (see also Langton 1991, 1995), which is plesiomorphously opposite to C. neocorax and C. brevidentatus.

Also the larvae of C. brevidentatus and C. neocorax resemble each other very much (see Fig. 4). The antennae of $C$. neocorax are a little longer, the last (6th) tooth of the mandibble and the 3rd tooth (counted from the lateral border) of the hypochilum are a little bit smaller in C. brevidentatus. The salinarius type larvae of "Chironomus sp. $2 n=6$, Lokka" described earlier by Michailova (1992) from the inundated Seitajärvi area in the eastern part of the Lokka reservoir resemble (as they also karyologically do) more the larvae of $C$. islandicus Kieffer because of the structure of the chaetae $(\mathrm{Ch})$ on the sensory field of labrum (Fig. 4). The setae $S_{1}$ also have certain similarity between these species because of the possibility to have a broad apical hair in it. Such an apical hair in $S_{\mathrm{I}}$ was found also in Chironomus sp. "Seitajärvi" described in Hirvenoja \& Michailova
(1997). (It was not confirmed if this species had ventral papillae, because only crumpled larval skins were available.) For the present it is not known if such a structure is a constant feature, because the setae $S_{I}$ are often difficult to observe.

Differences between the species of Chironomus, the larvae of which have no abdominal or ventral papillae and which are with certainty (karyologically) been shown from the Palearctic region can be characterized in the keys as follows.

\subsection{Chromosomes}

1. Chromosome set $2 n=8$. Ist ( $A B)$, 2nd (CD) chromosomes metacentric, 3rd (EF) submetacentric, IVth (G) telocentric ...................................................... 2

- Chromosome set $2 \mathrm{n}=6.1$ st $(\mathrm{AB}), 2 \mathrm{nd}(\mathrm{CD})$ and $3 \mathrm{rd}$ (EF) chromosomes metacentric. 4th (G) chromosome fused with chromosome EF

"Chironomus sp. $2 \mathrm{n}=6$, Lokka"

2. Homologues of 4 th (G) chromosome paired. Chromosome $\mathrm{G}$ with two Balbiani rings and one nucleolus. Arm $\mathrm{E}$ with one and the same banding pattern. ............ 3

- Homologues of 4th $(\mathrm{G})$ chromosome unpaired, without Balbiani ring, the chromosome structure very poor, with one nucleolus ............................. C. islandicus

3. Centromeres of all chromosomes are heterochromatized. Arm A with the following banding pattern 1-2c10-12-3-13-4-9-2d-k-14-19. The typical constriction of arm $\mathrm{C}$ is near to the telomere, not to the centromere .................................................... C. neocorax

- Centromeres of chromosomes AB,CD are not heterochromatized. Arm A with the following banding pattern: $1-2 c-10-12-3-2 d-13-2 k-6-5-4-7-8-9-14-$ 19.The typical constriction of arm $C$ is near to the centromere region C. brevidentatus

\subsection{Males}

In the key of Lindeberg and Wiederholm (1979: 105) C. islandicus must in the couplet 8 be compared with $C$. anthracinus Zetterstedt, but $C$. brevidentatus and $C$. neocorax in couplet 14 with C. venustus and $C$. longistylus.(The species are difficult to separate when present as single individuals only.)

\subsection{Females}

See the discussion above. 


\subsection{Pupae}

1. Intersegmental spinules present behind the shagreen of the tergite 4 and 5, patches of strong spinules lack near the anal-lateral corners of the sternite 4 or

C. islandicus

- Exuviae without intersegmental spinules behind the shagreen of the tergite 4 and 5. Patches of the strong spinules (resembling a little those of the "vortex" on the parasternite) near the postero-lateral corners of the sternite 4 or also of sternite 5 2

2. Parasternite 2 and 3 spinulated. Longer points abundantly on pleuralregion of segment 4 present. Paratergite 5-7 spinulated. Spinules absent on sternite 1 , but sternite 5 anteriorly and laterally clearly spinulated

C. neocorax

- All parasternites smooth. A few longer points may be present on the pleuralregion of segment 4. Paratergite 5 and 6 spinulated. Spinules on the posterior corners of sternite 1 , sternite 5 sparsely and variable spinulated . C. brevidentatus

\subsection{Larvae}

1. On the sensory field of the labrum the $C h$ feathered on the apical half leaving a short bare apex without hairs, the 3rd tooth of the hypochilum approximately as high as the 2 nd, but gives an impression of a small reduction of the size

- On the sensory field of the labrum the $C h$ with a long not feathered, bare apex, the 3 rd tooth (counted from the lateral border) of the hypochilum lower than the 2nd

2. The dorsal tooth of the premandible not much shorter than the ventral (outer) tooth. Antennal segments 3 and 4 about equal in length, 1 st segment about twice as long as the segments 2-5 together (antenne up to $170 \mu \mathrm{m}$ long, body length up to 14-15 mm)

"Chironomus sp. $2 \mathrm{n}=6$, Lokka"

- The dorsal tooth of the premandible clearly shorter than the ventral tooth. Antennal segment 4 longer than 3rd, 1 st segment about 3 times so long as the remaining together (antenne up to $190 \mu \mathrm{m}$ long, body length up to $16-18 \mathrm{~mm}$ ) C. islandicus

3. The dorsal, narrowly pointed tooth of the premandible about as long as the ventral tooth. The last tooth of the mandible about $1 / 2$ as broad as the 5 th tooth, the $3 \mathrm{rd}$ tooth of the hypochilum approximately as broad as the 2nd (length of the body up to $15 \mathrm{~mm}$; the total length of the antennae 140-160 $\mu \mathrm{m}$ ) .................. C. neocorax

- The dorsal tooth of the premandible clearly shorter than the ventral tooth. The last ( $6 \mathrm{th})$ tooth of the mandible about $1 / 3$ as broad as the 5 th tooth, the 3 rd tooth of the hypochilum narrower than the 2 nd (length of the boby up to $13 \mathrm{~mm}$; the total length of the antennae 120 $140 \mu \mathrm{m})$ C. brevidentatus

\section{The ecological conditions in Lokka reservoir}

The Lokka reservoir (about $27^{\circ} 40^{\prime} \mathrm{E}, 67^{\circ} 55^{\prime} \mathrm{N}$, area $413 \mathrm{~km}^{2}$, mean depth $3.7 \mathrm{~m}$, maximal amplitude of regulation $5.0 \mathrm{~m}$ ) in Sodankylä, northern Finland was filled for the first time 1968-1969. Because the reservoir is quite large, the present studies were restricted to the northern and eastern parts of Lokka. The coordinates (see Heikinheimo and Raatikainen 1971) of the sampling area of C. brevidentatus in June 1995 were $7544: 517$. Attempts were made to rear larvae in the field without any aeration and later at the room temperature (in southern Finland after the trip) in aerated conditions. A few adults emerged then during the two first weeks of July 1995, which may be the natural emergence period of $C$. brevidentatus in Lokka. (The lakes of the study region usually thaw roughly at about 20. May.)

The new species was not observed during the earlier trip in 1989 , when attempts were made to find especially such larvae, which belong to the "salinarius type", from the northern part of the reservoir. It is of course very probably, that the abundance of $C$. brevidentatus has increased in the reservoir only locally or, that there are differences between the years because of some unknown reasons. The conditions of the now about 25 year old reservoir have changed very much in the whole basin, but not clearly during the last ten years (see Itkonen 1996). Locally on the site studied they have changed for reasons among others because of the gradual reduction of the large peat rafts (see Ruuhijärvi et al. 1976). There was a great difference between the years 1989 and 1995 in the Seitajärvi area (coordinates 7544-7545 : 534-535), from which the peat rafts 1995 had disappeared. In 1989 the still quite closed lake area was widely direct open to the oligotrophic waters of the river Luiro. In 1984, during the more closed phase, there was a small difference in the water chemistry between lake Seitajärvi and the Lokka proper (see measurements of the author M.H. in Table 1).

The few "salinarius type larvae", all of which were described by Michailova (1992) as "Chironomus $2 \mathrm{n}=6$ ", were collected in 1989 from the shore areas (depth $<2 \mathrm{~m}$ ) of the still quite closed Lake Seitajärvi in the eastern part of the Lokka reservoir. 
The bottom of Lokka consists of peat and loose peat ooze and mud (dy). The loose mud is accumulated especially into the hollows as a thick layer, which the larvae of the chironomids seem to inhabit in large numbers. About $30-40$ species of chironomids have been captured from the swarms during our trips to the Lokka reservoir 1984-1995. The large Chironomus larvae have in Lokka ventral papillae of the "semireductus type" just like different species in mesotrophic lakes (cf. Sæther 1979a, 1979b). This agrees with the views about the water quality expressed in the botanical studies by Arvola (1980) and by Jones and llmavirta (1983), who approximated Lokka to be a mesotrophic biotope. Lepistö (1995) reports changes in the phytoplankton of Lokka from 1968 to 1990 , but mentions that the phytoplankton still indicates meso-eutrophic water. Among the largest species (karyologically P. Michailova det.) C. entis Shobanov was the most common in the Lokka reservoir. Also the sibling species C. plumosus Linnaeus sensu auctt. as well as several other species of Chironomus were present. In 1984 many abundant undeterminable species of Chironomus found in swarms were not found later among the rearings. Other studies about the chironomid fauna of Lokka at the species level are not available. Limnological studies about the changes of the Lokka reservoir have been carried out among others by Heinonen and Airaksinen (1974), Kinnunen $(1985,1991)$ and Hellsten et al. (1993); the interest of these authors were directed to other objects than the bottom fauna. $\mathrm{Ne}$ nonen and Nenonen (1972), however, already mentioned the occurrence of the "Chironomus plumosus type" larvae.

Lepistö and Pietiläinen (1996) and Itkonen (1996) have illustrated the changes of the water quality of Lokka measured by the water admin- istrators. During the last ten years according to these authors the $\mathrm{pH}$ values (6.5-6.7), alkalinity (about $0.10 \mathrm{mmol} / \mathrm{l}$ ) coloration (about $100 \mathrm{Pt} \mathrm{mg/}$ 1), $\mathrm{COD}_{\mathrm{Mn}}\left(8-10 \mathrm{mg} \mathrm{O}_{2} / \mathrm{l}\right)$, conductivity (near 2.0 $\mathrm{mS} / \mathrm{m}) \mathrm{N}_{\text {tot }}$ (about $\left.500 \mu \mathrm{g} / \mathrm{l}\right), \mathrm{P}_{\text {tot }}(30-40 \mu \mathrm{g} / \mathrm{l})$ and $\mathrm{Fe}(600-800 \mu \mathrm{g} / \mathrm{l})$ have, in comparison to the 15 first years, stayed quite stable. Beginning from 1982 the regulation of the water level has been only about $3 \mathrm{~m}$ instead of the maximal allowed 5 $\mathrm{m}$. The oxygen concentration in winter has been near zero in the deep places, but according to Kinnunen (1991), and Salo (1995, 1996) there has always been oxygen enough for the fishes under the ice or in the areas, which have been influenced by the rivers. According to the results of Salo $(1995,1996)$ the oxygen concentration seems have to been in April 1995 even a little bit better in the whole reservoir than in 1994.

The area of the samples, where C. brevidentatus sp.n. in June 1995 was surprisingly abundantly found, belongs to the part of the reservoir, through which the waters according to Virtanen et al. (1993:37) since 26.XI.1981 have flowed from the southern and eastern part of the reservoir to the next dam basin of Porttipahta. There are in the east-northeastern part of Lokka the inlets of two rivers, which may have 1995 (or since the precisely unknown time of the opening of the Seitajärvi way to the waters of the river Luiro) influenced more strongly to the oxygen concentration of the waters near the bottom mud on the deep sites of the study area. Unfortunately, these are only suggestions, which would need studies in other parts of the reservoir for their confirmation. From the shallow (depth about $2 \mathrm{~m}$ ) shore areas the "salinarius or plumosus type larvae" were not captured, but in this area in June 1995 especially Potthastia longimanus Kieffer, Dicrotendipes nervosus (Staeger) and parthenogenetic females of

Table 1. Measurements of the water chemistry in different parts of the Lokka reservoir during a trip to Lokka at 18-22. June 1984 from its most northern part, the inundated lake Sompiojärvi, to its most eastern part, the inundated lake Seitajärvi.

\begin{tabular}{lccc}
\hline & (Sompiojärvi) & Lokka & (Seitajärvi) \\
\hline Coloration Pt mg/l & 50 & 70 & 70 \\
Conductivity $\mathrm{mS} / \mathrm{m}\left(\mathrm{g}_{25}\right)$ & 1.9 & 2.0 & 2.1 \\
$\mathrm{pH}$ & 7.1 & 6.8 & 6.5 \\
$\mathrm{~N}_{\text {tol }} \mathrm{mg} / \mathrm{l}$ & $<0.01$ & 0.70 & 1.54 \\
$\mathrm{P}_{\text {tol }} \mathrm{mg} / \mathrm{l}$ & 0.02 & 0.03 & 0.05 \\
\hline
\end{tabular}




\section{Corynoneura sp. and Tanytarsus sp. emerged in the funnel trap used here in some days.}

Acknowledgements: We are indebted to Drs. Pekka Kansanen (Helsinki), Claus Lindegard (Copenhagen), and Jon S. Olafsson (Reykjavik) for the comparison materials, to Mrs. Elina Hirvenoja, Mag. Phil., for the assistance in the collection of the material and to Mr. Donald Smart for the English language revision.

\section{References}

Arvola, L. 1980: On the species composition and biomass of the phytoplankton in the Lokka reservoir, northern Finland. - Ann. Bot. Fennici 17: 325-335.

Butler, M. G. 1982: Morphological and Phenological delimitation of Chironomus prior sp.n. and C.tardus sp.n. (Diptera: Chironomidae), sibling species from arctic Alaska. - Aquatic Insects 4: 219-235.

Goetghebuer, M. 1921: Chironomides de Belgique et spécialement de la zone des Flanders. - Mém. Mus. R. Hist. Nat. Belg. 8 (Fasc. 4), Mém. 31: 1-208.

Heikinheimo, O. \& Raatikainen, M. 1971: Paikan ilmoittaminen Suomesta talletetuissa biologisissa aineistoissa (The recording of localities of biological finds in Finland). - Ann. Entomol. Fenn. 37 (1a): 1-27.

Heinonen, P. \& Airaksinen, E. 1974: Lokan ja Porttipahdan tekojärvien tilan kehittymisestä vuosina 1971-1974. — Vesihallitus, Tiedotus 77: 1-51.

Hellsten, S. K., Virtanen, M. O., Nenonen, O. S., Kinnunen, K. A. \& Riihimäki, J. M. 1993: Relative importance of internal sources of phosphorus and organic matter in northern Finnish reservoirs. - Wat. Sci. Tech. 28 (6): 85-94.

Hirvenoja, M. \& Michailova, P. 1997: On the karyology and morphology of Chironomus jonmartini (Dipt., Chironomidae), - Entomol. Fennica 8: 39-55

Itkonen, J. 1996: Lausunto Vuotoksen altaan veden laadun kehittymisestä sekä altaan vaikutuksesta Kemijoen, Kemijärven ja Perämeren tilaan. - Vuotoksen tekojärven ja voimalaitoksen rakentamista ja säännöstelyä koskevan vesioikeudellisen katselmustoimituksen katselmuskirjan liite 12 (Mimeography). 127 pp.

Jones, R. I. \& Ilmavirta, V. 1983: Spatial heterogeneity of phytoplankton in the Lokka reservoir, Finnish Lapland. - Ann. Bot. Fennici 20: 391-397.

Keyl, H. 1962: Chromosomenevolution bei Chironomus. II. Chromosomenbauten und phylogenetische Beziehungen der Arten. - Chromosoma 113: 464-514.

Kinnunen, K. 1985: Lokan ja Porttipahdan tekoaltaiden sekä niiden alapuolisten jokien tilan kehittyminen vuoteen 1984 saakka. — Lapin vesipiiri (Mimeography): 1-73 +10 appendages.

Kinnunen, K. 1991: Lapin tekoaltaiden veden laadun kehittyminen ja vaikutus alapuolisten vesien ainevirtaamiin. - University of Oulu. Res. Inst. of Northern Finland. Res. Rep. 104: 59-70
Langton, P. H. 1991: A key to pupal exuviae of West Palearctic Chironomidae. - Mimeogr. 386 pp.

Langton, P. H. 1995: Update on the genus Chironomus (A key to pupal exuviae of West Palearctic Chironomidae). - Mimeogr. 14 pp.

Lepistö, L. 1995: Phytoplankton succession from 1968 to 1990 in the subarctic Lokka reservoir. - National Board Wat. Env. Finland, Publ. Wat. Env. Res. Inst. 19: $1-41$

Lepistö, L. \& Pietiläinen, O.-P. 1996: Kasviplanktonin määrän ja koostumuksen muutokset Lokassa, Porttipahdassa ja Kemijärvessä. (English summary: Changes in the quantity and composition of phytoplankton in two reservoirs, Lokka and Porttipahta and in Lake Kemijärvi). - Suomen ympäristö 13: 1-73 + 5 appendages.

Lindeberg, B. \& Wiederholm, T. 1979: Notes on the taxonomy of European species of Chironomus (Diptera: Chironomidae). - Entomol. Scand. Suppl. 10: 99-116.

Michailova, P. 1989: The polytene chromosomes and their significance to the systematics of the family Chironomidae, Diptera. - Acta Zool. Fennica 1986: 1-107.

Michailova, P. 1992: Karyosystematics and morphology of Chironomus salinarius type larvae (Diptera, Chironomidae) from Finland. - Cytobios 71: 163-169.

Nenonen, O. \& Nenonen, M. 1972: Havaintoja Lokan ja Porttipahdan tekoaltaista. - Vesihallitus. Tiedotus 21: $1-16+45$ app.

Pinder, L. C. V. 1978: A key to adult males of British Chironomidae 1-2. - Freshw. Biol. Assoc. Scient. Publ. 37: $1-169+189$ fig.

Ruuhijärvi, R., Alapassi, M. \& Heikkinen, P. 1976: Lokan tekoaltaan turvelauttatutkimus. - Mimeography, Helsinki 1976: 1-49.

Sæther, O. A. 1979a: The influence of eutrophication on deep lake benthic invertebrate communities. - Prog. Wat. Tech. 12: 161-180.

1979b: Chironomid communities as water quality indicators. - Holarctic Ecol. 2: 65-74.

Salo, O. 1995: Lokan ja Porttipahdan tekojärvien ja niiden alapuolisten jokien vedenlaadun tarkkailun tulokset 1994. - Kemijoki Oy / Lapin vesitutkimus Oy, Mimeography 1-26+7 appendages.

Salo, O. 1996: Lokan ja Porttipahdan tekojärvien ja niiden alapuolisten jokien vedenlaadun tarkkailun tulokset 1995. — Kemijoki Oy / Lapin vesitutkimus Oy, Mimeography $1-25+5$ appendages.

Zav̌rel, J. 1926: Netznámé ústroje kukel rodu Chironomus. - Casopis “Ceskoslovensko Spolecnosti Entomol. 22: 89-92.

Webb, D. W. 1969: New species of chironomids from Costello Lake, Ontario (Diptera: Chironomidae). - J. Kansas ent. Soc. 42: 91-108.

Virtanen, M., Hellsten, M., Koponen, J. Riihimäki, J. \& Nenonen, O. 1993: Pohjoisten tekojärvien veden laadun laskenta mittauksilla varmistettuna. - VTT Tiedotteita 1525: 1-205 + 3 app.

Wülker, W. 1991: Chromosomal, morphological and biological differences between Chironomus tenuistylus Brundin and C. longistylus Goetghebuer (Diptera: Chi- 
ronomidae) in Fennoscandia and the USA. - Ent. scand. 22: 231-240.

Wülker, W. \& M. G. Butler 1983: Karyosystematics and morphology of northern Chironomus (Diptera: Chironomidae): Freshwater species with larvae of the salinarius-type. - Entomol. Scand. 14: 121-136. 